\title{
Detection and identification of the phytoplasma associated with China ixeris (Ixeridium chinense) fasciation
}

\author{
Zheng-Nan $\mathrm{Li}^{1 \dagger}$, Ping Liu ${ }^{1 \dagger}$, Lei Zhang ${ }^{2}$ and Yun-Feng $\mathrm{Wu}^{1 *}$
}

\begin{abstract}
Background: Phytoplasmas are always associated with symptoms in host plants such as stunting of stems, witches'-broom, yellowing of leaves, formation of sterile-deformed flowers, virescence and phyllody. Recently also symptom of fasciation was reported associated with phytoplasma presence. In the present work, China ixeris fasciation was observed associated with phytoplasmas in Guanzhong Area, Shaanxi, China.

Results: Phytoplasma-like bodies were observed under transmission electron microscope in stem tissues of symptomatic samples. The $16 \mathrm{~S}$ rRNA operon and tuf genes from phytoplasmas were amplified by PCR assays. Phylogenetic trees were calculated respectively based on sequences data of these two genes. The pattern of restriction fragment length polymorphism (RFLP) was generated via digesting the PCR products of 16S rRNA gene with eight restriction enzymes.

Conclusion: The presence of phytoplasma in China ixeris exhibiting fasciation symptom was confirmed by the results of TEM observation and PCR testing. Based on sequence data, phylogeny analysis and actual restriction fragment length polymorphism (RFLP) analysis, the associated phytoplasma was classified as related to $16 \mathrm{Srl}-\mathrm{C}$ subgroup. This was the first record of phytoplasmas in China ixeris.
\end{abstract}

Keywords: Transmission electron microscopy; $16 \mathrm{~S}$ rRNA and tuf genes; PCR; Phylogeny analysis; RFLP

\section{Background}

Fasciation is a result of an aberrant growth development in plants. A fasciated plant often forms flattened, wider than normal stems similar to a multiple stem fusion. This abnormal phenotype is observable in many plant species in nature, and spontaneous genetic mutations, bacterial infections, insect or mite attacks, physically wounding or herbicide sprays were reported causing plant fasciations (Goethals et al., 2001). More recently, phytoplasma were detected in some plants exhibiting fasciation symptom (Bertaccini et al., 2005; Poncarová-Vorácková et al., 1998; Fránová and Petrzik, 2010; Kumar et al., 2010; Wu et al., 2012; Li et al., 2012).

\footnotetext{
*Correspondence: wuyf@nwsuaf.edu.cn

${ }^{\dagger}$ Equal contributors

'State Key Laboratory of Crop Stress Biology for Arid Areas/Key Laboratory of Integrated Pest Management on Crop in Northwestern Loess Plateau,

Ministry of Agriculture/Key Laboratory of Plant Protection Resources and Pest Management, Ministry of Education, College of Plant Protection, Northwest

A\&F University, Yangling 712100, Shaanxi Province, P. R. China

Full list of author information is available at the end of the article
}

Phytoplasmas were assigned to a provisional genus, 'Candidatus Phytoplasma' within the class Mollicutes (IRPCM, 2004). They are cell-wall-less prokaryotes that inhabit plant phloem system, associated with symptoms such as stunting of stems, proliferation of axillary shoots (witches'-broom), yellowing of leaves, formation of steriledeformed flowers, greening of floral tissues (virescence) and forming of leaf-like flower organs (phyllody). Since phytoplasmas have just been cultured under axenic conditions recently (Contaldo et al., 2012), their diagnosis still depends on molecular analysis of several evolutionarily conserved genes like $16 \mathrm{~S}$ ribosomal RNA (rRNA), ribosomal protein $(r p)$ and elongation factor TU (tuf). So far, a total of 31 phytoplasma groups and over 50 subgroups were found based on analysis of $16 \mathrm{~S}$ rRNA gene sequences (Wei et al., 2007; Zhao et al., 2009; Lee et al., 2011).

China ixeris [Ixeridium chinense (Thunb.) Tzvel.] is a perennial herb of the family Compositae, which could be used as traditional Chinese herbal medicine for treatment of enteritis and cholecystitis (Liu et al. 2010). 
In this report, China ixeris fasciation disease occurrence is described and a phytoplasma related to $16 \mathrm{SrI}-\mathrm{C}$ subgroup was associated with the symptomatology described.

\section{Methods \\ Sample collection}

In May 2009, China ixeris fasciation was observed in Guanzhong Area, Shaanxi Province, China. To verify disease aetiology, 30 symptomatic and three asymptomatic plants were collected in field. Some China ixeris plants were also transplanted into an insect-proof greenhouse for observation of symptom development.

\section{Transmission electron microscopy}

Fasciated stems of ca. $2 \times 2 \mathrm{~mm}^{2}$ from symptomatic samples were processed for transmission electron microscope examination. The tissues were fixed in a buffer $(\mathrm{pH} 7.2)$ containing $3 \%(\mathrm{v} / \mathrm{v})$ glutaraldehyde and $4 \%(\mathrm{v} / \mathrm{v})$ paraformaldehyde, incubated at $4^{\circ} \mathrm{C}$ for $4 \mathrm{~h}$, and subsequently in $1 \%(\mathrm{v} / \mathrm{v})$ osmium tetroxide at room temperature for $2 \mathrm{~h}$. Then the fixed samples were dehydrated in concentration gradients of ethanol (10-70\%) and acetone (0-100\%), and finally were embedded in Epon 812 Kamińska et al., (2001). The ultra-thin sections were stained with uranyl acetate and led citrate, and then examined.

\section{PCR amplification}

Total DNA of each sample was extracted following cetyltrimethyl ammonium bromide (CTAB) method (Kollar et al., 1990), and used as template in PCR assays. Total DNA of samples infected with a phytoplasma related to wheat blue dwarf phytoplasma (WBDp) (16SrI-C subgroup) (Wu et al., 2010) and chinaberry witches' broom phytoplasma (CWBp) (16SrI-B subgroup) (Wu et al., 2010) were as positive controls.

Primers P1 (Deng and Hiruki, 1991) and P7 (Schneider et al., 1995) were used in amplification of phytoplasma 16S rRNA gene, spacer region between $16 \mathrm{~S}$ and $23 \mathrm{~S}$ rRNA genes and the start of 23S rRNA gene. The PCR products were diluted 1: 29 with sterile double-distilled water prior to the nested amplification using the general primer pair R16F2n/R2 (Gundersen and Lee, 1996). Each PCR mixture $(25 \mu \mathrm{L})$ contained: $2 \mu \mathrm{L}$ DNA template (10 ng/uL), $1 \mu \mathrm{L}(10 \mathrm{pM})$ of each primer, $2 \mu \mathrm{L}$ dNTP (2.5 mM), $2 \mu \mathrm{L} \mathrm{MgCl}_{2}(25 \mathrm{mM}), 2.5 \mu \mathrm{L} 10 \times$ Taq buffer and $1 \mathrm{U}$ Taq DNA polymerase (Thermo Fisher Scientific Inc.), and sterile double-distilled water to the final volume. The PCR amplification program was as follows: preheating at $94^{\circ} \mathrm{C}$ for $3 \mathrm{~min}$, and then subjected them to 35 amplification cycles, of denaturation at $94^{\circ} \mathrm{C}$ for $1 \mathrm{~min}$, annealing at $50^{\circ} \mathrm{C}$ for $1 \mathrm{~min}$, and extension at $72^{\circ} \mathrm{C}$ for $1 \mathrm{~min}$, with a final elongation of $72^{\circ} \mathrm{C}$ for $10 \mathrm{~min}$.

Amplification of phytoplasma tuf gene was primed by primer pair fTufu/rTufu (Schneider and Gibb, 1997).
The reaction mixture was set as above. After 3 minutes' preheating at $94^{\circ} \mathrm{C}, 30$ amplification cycles were carried out: denaturation at $94^{\circ} \mathrm{C}$ for $30 \mathrm{~s}$, annealing at $50^{\circ} \mathrm{C}$ for $30 \mathrm{~s}$ and extension at $72^{\circ} \mathrm{C}$ for $1 \mathrm{~min}$, with a final elongation of $72^{\circ} \mathrm{C}$ for $10 \mathrm{~min}$.

PCR products were separated in $1 \%$ agarose gel by electrophoresis, stained with ethidium bromide and visualized using UV transilluminator.

\section{Cloning, sequencing and sequence analysis}

PCR products of $1.8 \mathrm{~kb}$ (phytoplasma 16S rRNA gene) and $0.8 \mathrm{~kb}$ (tuf gene) were purified using a commercial PCR Purification Kit (Bio Teke Corporation, Beijing, China) and cloned. The clones contained recombinant plasmid were selected by blue-white screen and for each sample, three clones were selected and sequenced by TaKaRa Biotechnology (Dalian) Co., Ltd. The primers used for sequencing of $16 \mathrm{~S}$ rRNA gene were M13F(-47): CG CCAGGGTTTTCCCAGTCACGAC/M13R(-48): AGCG GATAACAATTTCACACAGGA and of tuf gene were M13F(-77): GATGTGCTGCAAGGCGATTA/M13R(-48), which were designed based on the sequence of pMD18-T simple vector and offered by the TaKaRa Biotehnology Co. Ltd.

Sequences were aligned using the Lasergene software (version 7.0; DNASTAR, Madison, USA) and used for searching against the database of National Center for Biotechnology Information (NCBI) by BLASTn.

Published phytoplasma sequences were retrived from GenBank; 33 sequences of $16 \mathrm{~S}$ rRNA gene and 17 sequences of tuf genes from groups 16SrI, -III, -V, -X and -XII were selected. Phylogenetic trees were built by neighborjoining (16S rRNA) or maximum parsimony (tuf gene) methods with a 1000-replicate bootstrap search using MEGA4 (Saitou and Nei, 1987; Tamura et al., 2007).

The nested PCR products of $16 \mathrm{~S}$ rRNA gene $(1.2 \mathrm{~kb})$ from symptomatic samples were concentrated, and digested with eight restriction enzymes AluI, BfaI, HaeIII, HhaI, HpaII, KpnI, MseI and RsaI (Lee et al., 1998). The digested PCR products were separated in $8 \%$ polyacrylamide gel by electrophoresis and visualized using UV tranilluminator after ethidium bromide staining.

\section{Results}

In field, the phytoplasma-infected China ixerises exhibited symptoms of curving and flat stem (Figure 1A, 1C), narrow leaves (Figure 1B) and clustering of multiinflorescence (Figure 1D). The disease was named China Ixeris fasciation (ChIF). After two months' observation of field-collected China Ixerises for symptom development in green house, the flat stem did not broaden and the abnormal flowers did not seed.

In ultra-thin sections of fasciated stems from symptomatic samples, many phytoplasma-like bodies (PLBs) 


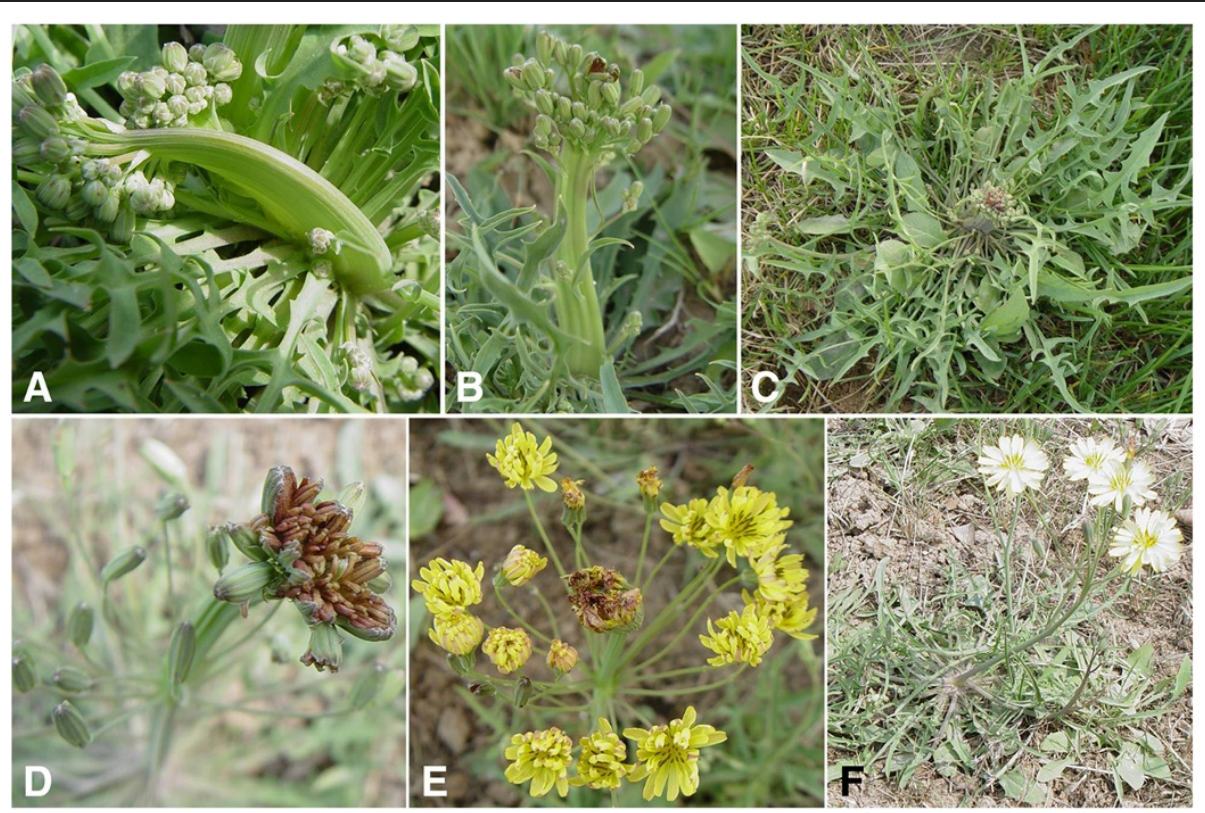

Figure 1 Symptoms of phytoplasma-infected China ixeris. The symptoms are curving stem (A); flat stem, shorting stalk (C); narrowing leaves (B) and clustering of multi-inflorescence (D), compared to healthy one (E).

were identified based on the spherical and dumbbellshaped structures under TEM (Figure 2). The PLBs ranged from 330 to $700 \mathrm{~nm}$ in diameter and contained ribosome-like bodies and a central region of fibrillar material, presumed to contain DNA.

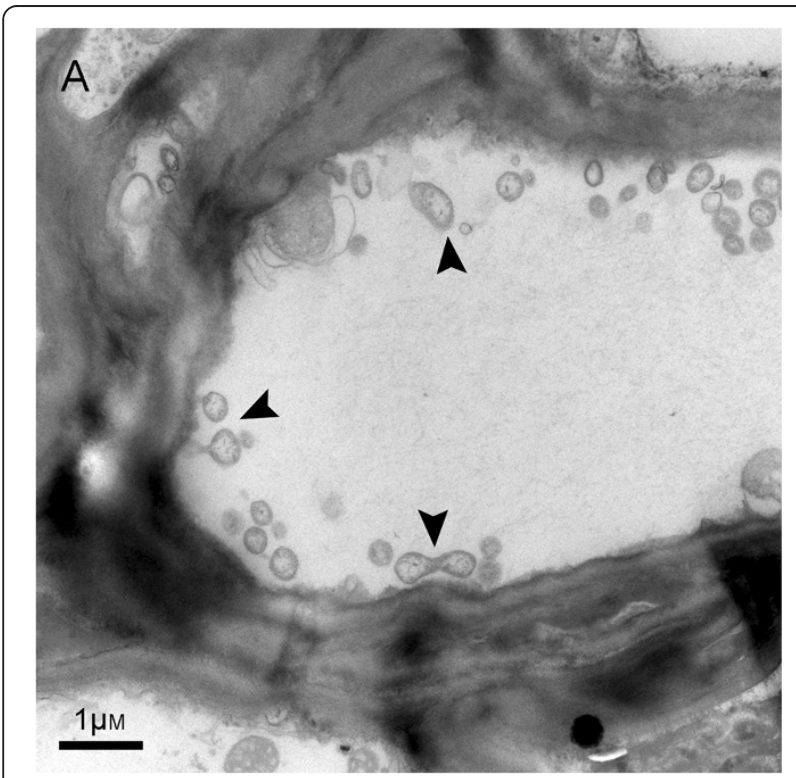

Figure 2 Transmission electron micrograph of phytoplasma-like bodies (indicated by black narrow) in stem tissues of symptomatic China ixeris. Scale bar $=1 \mu \mathrm{m}$.
From all 30 total DNA of symptomatic samples and positive controls, PCR products of $0.8 \mathrm{~kb}$ (partial tuf gene), $1.8 \mathrm{~kb}$ and $1.2 \mathrm{~kb}$ (partial $16 \mathrm{~S}$ rRNA gene) were generated, but no PCR product was obtained from the asymptomatic samples.

The sequences of $1,840 \mathrm{bp}$ generated from symptomatic samples were identical between each other and deposited under GenBank under accession no. HM990973. The obtained sequences of $842 \mathrm{bp}$ ( $t u f$ gene), share $100 \%$ of identity and were deposited under accession no. HM990972. NCBI BLASTn program analysis indicated that the sequences of 1,840 bp and $842 \mathrm{bp}$ were homogenous to sequences of group 16SrI phytoplasmas. The HM990973 shared the highest identity of $99.67 \%(1,834 \mathrm{bp} / 1,840 \mathrm{bp})$ with clover phyllody phytoplasma strain $\mathrm{CPh}$ (accession no. AF222065) and Poa stunt phytoplasma (accession no. DQ640501), and the HM990972 had the identity of 100\% with clover phyllody phytoplasma strain KV (accession no. L46369) and Wheat blue dwarf phytoplasma (accession no. DQ507200).

As indicated by the phylogenetic trees inferred from $16 \mathrm{~S}$ rRNA genes (Figure 3) and tuf genes (Figure 4), the ChIFp and phytoplasmas of group $16 \mathrm{SrI}$ clustered together.

ChIFp yielded the same RFLP pattern with WBDp, but differ from CWBp in HaeIII and HhaI sites (Figure 5). After digested with enzyme HhaI, ChIFp and WBDp generated two bands of 872 and $310 \mathrm{bp}$, while CWBp got three bands of 872, 118 and $72 \mathrm{bp}$. And both ChIFp and WBDp yielded the bands of 1,078 and $118 \mathrm{bp}$ after 


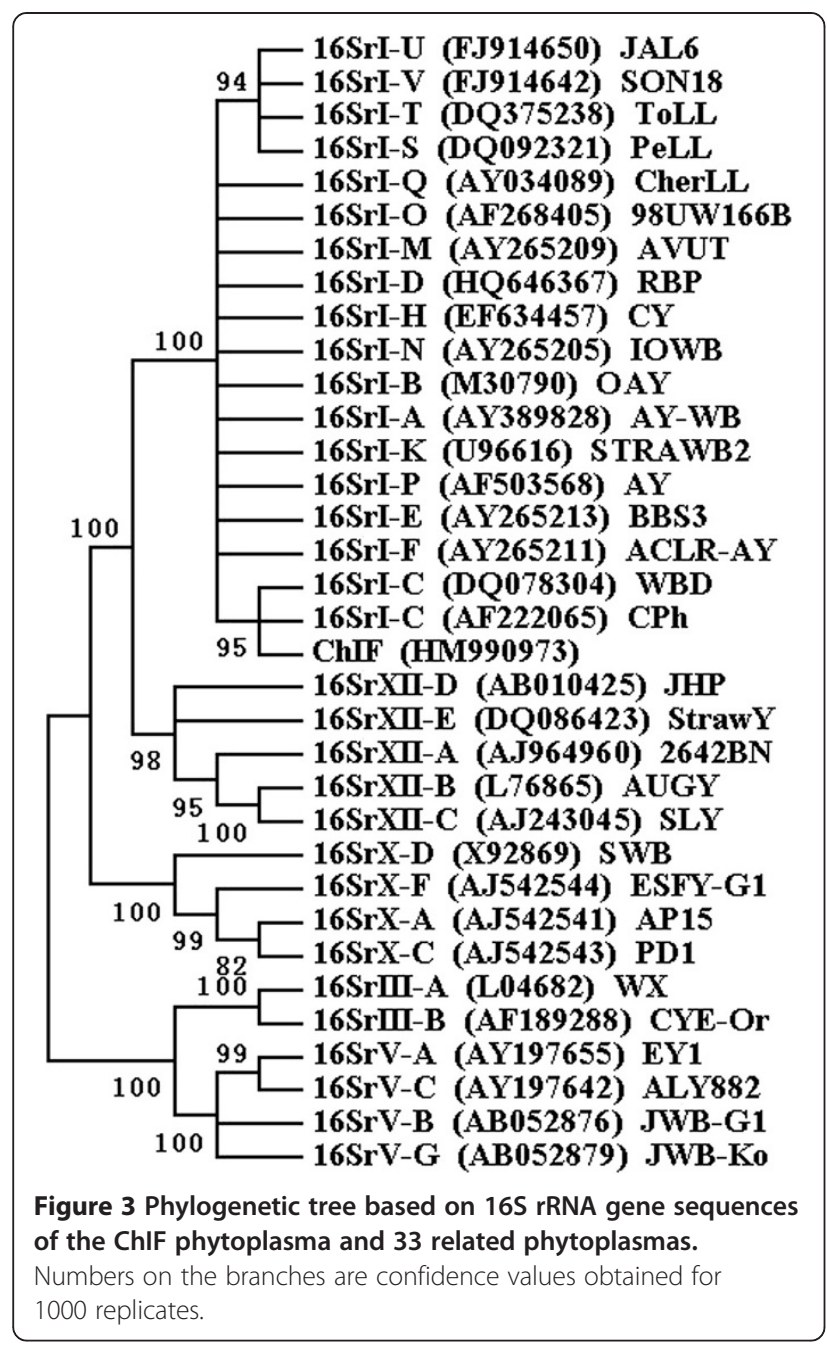

digestion with enzyme HaeIII, whereas the CWBp got bands of 1,078 and $72 \mathrm{bp}$. The results suggest close correlation of ChIp and WBDp with phytoplasmas in subgroup 16SrI-C although no identical to published reference strains.

\section{Discussion}

Based on TEM examination, PCR assays, sequencing, phylogeny and RFLP, phytoplasmas related to $16 \mathrm{SrI}-\mathrm{C}$ subgroup were detected as associated with fasciation in China ixeris. There are other reports of similar association such as fasciation in lilies (Lilium martagon; Liliaceae) (Bertaccini et al., 2005; Poncarová-Vorácková et al., 1998), Asparagus officinalis (Liliaceae) (Fránová and Petrzik, 2010), Crotalaria spectabilis Roth. (Fabaceae) (Kumar et al., 2010), Sunshine tree (Senna surattensis Burm. Caesapiniaceae) (Wu et al., 2012) and Puna chicory (Cichrium intybus L.) (Li et al., 2012). All the cases suggested that fasciation is a significant symptom for phytoplasma disease.

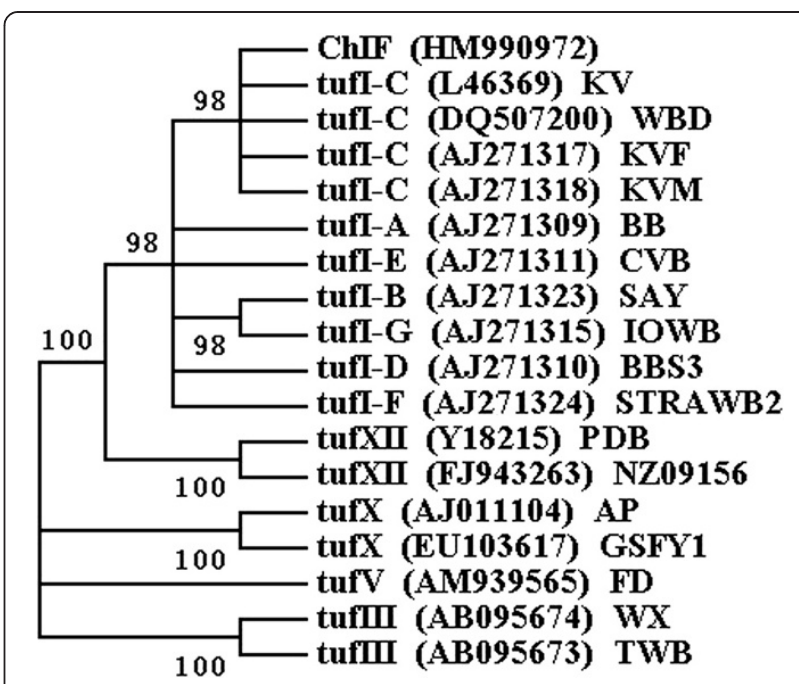

Figure 4 Phylogenetic tree based on tuf gene sequences of ChIF phytoplasma and related 17 phytoplasmas, constructed by the maximum parsimony method. Numbers on the branches are confidence values obtained for 1000 replicates.

Phytoplasmas related to $16 \mathrm{SrI}-\mathrm{C}$ subgroup were found in wheat (Wu et al., 2010) and so far, only two other host plants have been reported to host this kind of pathogen in China: peach trees (Zhang et al., 2013) and China ixeris and all reported in Shaanxi Province. Sequences analysis indicated that the identities of 16S rRNA genes of ChIFp (accession no. HM990973) and WBDp (accession no. DQ078304) [or peach red leaf phytoplasma (PRLp) (accession no. JX481781)] were $99.84 \%(1,244 \mathrm{bp} / 1,246 \mathrm{bp})$ [or 99.60\% (1,241 bp/1,246 bp)], and the tuf genes of ChIFp (accession no. HM990972) and WBDp (accession no. DQ507200) were identical to each other. China ixeris is widely distributed as a volunteer plant and always grew in or around cultivated fields like wheat field. So it can be a significant alternative host plant for this phytoplasma. China ixeris is also a new host plant for phytoplasmas.

\section{Conclusion}

China ixeris fasciation was confirmed associated with phytoplasmas based on results of TEM observation and PCR testing. Analyzing with the sequences of $16 \mathrm{~S}$ rRNA gene and tuf gene of the phytoplasma suggested the phytoplasma belongs to group 16SrI, After digesting with eight enzymes, the fragments of 16S rRNA gene of the phytoplasma yielded special patterns which were consistent with the patterns for phytoplasmas of subgroup 16 SrI-C in eight enzymes HpaII, Hhal, HaeIII, BfaI, $K p n \mathrm{I}$ and RsaI sites, but different in $A l u \mathrm{I}$ and MseI sites. The restriction fragment length polymorphism (RFLP) analysis supported that the associated phytoplasma was classified as related to $16 \mathrm{SrI}-\mathrm{C}$ subgroup. This was the first record of phytoplasmas in China ixeris. 


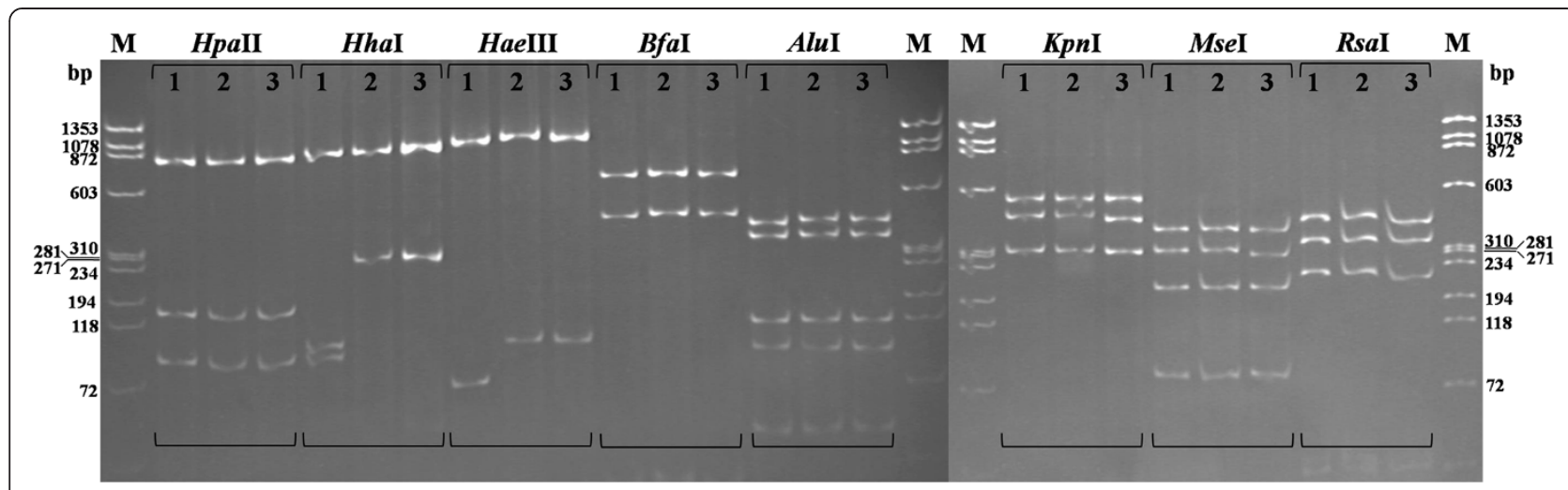

Figure 5 RFLP pattern of 16S rRNA gene digested with eight enzymes Hpall, Hhal, Haell, Bfal, Alul, Kpnl, Msel and Rsal. Lane M: ФX174 DNA ladder. 1, chinaberry witches'-broom. 2, China Ixeris fasciation. 3, wheat blue dwarf.

\section{Abbreviations}

rRNA: Ribosomal RNA; tuf: Elongation factor TU; CTAB: Cetyltrimethyl ammonium bromide; WBDp: Wheat blue dwarf phytoplasma; CWBp: Chinaberry witches' broom phytoplasma; ChIF: China ixeris fasciation; UV: Ultra violet; TEM: Transmission electron microscope.

\section{Competing interests}

The authors declare that they have no competing interests.

\section{Authors' contributions}

Z-NL and PL collected the samples, carried out the molecular experiments and analyzed with the sequence data, and drafted the manuscript. LZ carried out the observation with transmission electron microscope and processed all the pictures. Y-FW funded and directed the experiment. All authors read and approved the final manuscript.

\section{Acknowledgements}

We thank Dr. Frnak M You of Cereal Research Centre, Agriculture and AgriFood Canada for revisions and suggestions to the manuscript. This research was supported by the 111 project (Grant no. B07049) and the Ph.D. Program Foundation from the Ministry of Education of China (Grant no. 20100204110004), National Natural Science Foundation of China (Grant no. 31371913) and PhD Student Academic Newcomer Award of China Ministry of Education (Grant no. Z107021202)

\section{Author details}

${ }^{1}$ State Key Laboratory of Crop Stress Biology for Arid Areas/Key Laboratory of Integrated Pest Management on Crop in Northwestern Loess Plateau, Ministry of Agriculture/Key Laboratory of Plant Protection Resources and Pest Management, Ministry of Education, College of Plant Protection, Northwest A\&F University, Yangling 712100, Shaanxi Province, P. R. China. ${ }^{2}$ College of Forestry, Northwest A\&F University, Yangling, Shaanxi 712100, P. R. China.

Received: 23 May 2013 Accepted: 23 October 2013

Published: 31 October 2013

\section{References}

Bertaccini A, Fránová J, Botti S, Tabanelli D (2005) Molecular characterization of phytoplasmas in lilies with fasciation in the Czech Republic. FEMS Microbiol Lett 249:79-85

Contaldo N, Bertaccini A, Paltrinieri S, Windsor HM, Windsor GD (2012) Axenic culture of plant pathogenic phytoplasmas. Phytopathol Mediterr 51:607-617

Deng S, Hiruki C (1991) Amplification of 165 rRNA genes from culturable and nonculturable Mollicutes. J Microbiol Methods 14:53-61

Fránová J, Petrzik K (2010) Asparagus officinalis: a new host of 'Candidatus phytoplasma asteris'. J Phytopathol 158:317-320

Goethals K, Vereecke D, Jaziri M, Van Montagu M, Holsters M (2001) Leafy gall formation by Rhodococcus fascians. Annu Rev Phytopathol 39:27-52
Gundersen DE, Lee IM (1996) Ultrasensitive detection of phytoplasmas by nestedPCR assays using two universal primer pairs. Phytopathol Mediterr 35:144-151

IRPCM Phytoplasma/Spiroplasma Working Team - Phytoplasma Taxonomy Group (2004) 'Candidatus Phytoplasma', a taxon for the wall-less, non-helical prokaryotes that colonize plant phloem and insects. Int I Syst Evol Microbio 54:1243-1255

Kamińska M, Dziekanowska D, Rudzińska-Langwald A (2001) Detection of phytoplasma infection in rose, with degeneration symptoms. J Phytopathol 149:3-10

Kollar A, Seemüller E, Bonnet F, Saillard C, Bove J (1990) Isolation of the DNA of various plant pathogenic mycoplasmalike organisms from infected plants. Phytopathology 80:233-237

Kumar S, Singh V, Lakhanpaul S (2010) First report of Crotalaria spectabilis fasciation associated with 'Candidatus Phytoplasma asteris' in India. Plant Dis 94:1265, 1265

Lee IM, Gundersen-Rindal DE, Davis RE, Bartoszyk IM (1998) Revised classification scheme of phytoplasmas based on RFLP analyses of 16S rRNA and ribosomal protein gene sequences. Int JSyst Bacteriol 48:1153-1169

Lee IM, Bottner-Parker KD, Zhao Y, Villalobos W, Moreira L (2011) 'Candidatus Phytoplasma costaricanum' a novel phytoplasma associated with an emerging disease in soybean (Glycine max). Int I Syst Evol Microbiol 61:2822-2826

Li ZN, Zhang L, Bai YB, Liu P, Wu YF (2012) Detection and identification of the elm yellows group phytoplasma associated with Puna chicory flat stem in China. Can J Plant Pathol 34:34-41

Liu SM, Xie WD, Meng FJ (2010) Research progress in chemical compositions and pharmacologica activities of ixeris Cass. Lishizhen Medicine And Material Medica Research 21:975-977

Poncarová-Vorácková Z, Fránová J, Válová P, Mertelik J, Navrátil M, Nebesárová J (1998) Identification of phytoplasma infecting Lilium martagon in the Czech Republic. J Phytopathol 146:609-612

Saitou N, Nei M (1987) The neighbor-joining method: a new method for reconstructing phylogenetic trees. Mol Biol Evol 4:406-425

Schneider B, Gibb KS (1997) Sequence and RFLP analysis of the elongation factor Tu gene used in differentiation and classification of phytoplasmas. Microbiology 143:3381-3389

Schneider B, Seemüller E, Smart C, Kirkpatrick B (1995) Phylogenetic classification of plant pathogenic mycoplasma-like organisms or phytoplasmas. In: Razin $\mathrm{S}$, Tully JG (eds) Molecular and diagnostic procedures in mycoplasmology. Academic, New York, pp 369-380

Tamura K, Dudley J, Nei M, Kumar S (2007) MEGA4: molecular evolutionary genetics analysis (MEGA) software version 4.0. Mol Biol Evol 24:1596-1599

Wei W, Davis RE, Lee M, Zhao Y (2007) Computer-simulated RFLP analysis of $16 \mathrm{~S}$ rRNA genes: identification of ten new phytoplasma groups. Int J Syst Evol Microbiol 57:1855-1867

Wu Y, Hao X, Li Z, Gu P, An F, Xiang J, Wang H, Luo Z, Liu J, Xiang Y (2010) Identification of the phytoplasma associated with wheat blue dwarf disease in China. Plant Dis 94:977-985 
Wu W, Cai H, Wei W, Davis R, Lee IM, Chen H, Zhao Y (2012) Identification of two new phylogenetically distant phytoplasmas from Senna surattensis plants exhibiting stem fasciation and shoot proliferation symptoms. Ann Appl Biol 160:25-34

Zhang L, Li ZN, Zhang HW, Tao Y, Wu YF (2013) Detection and identification of aster yellows group phytoplasma (16Srl-C) associated with peach red leaf disease. J Phytopathol 161:359-362

Zhao Y, Wei W, Lee M, Shao J, Suo X, Davis RE (2009) Construction of an interactive online phytoplasma classification tool, iPhyClassifier, and its application in analysis of the peach X-disease phytoplasma group (16Srill). Int J Syst Evol Microbiol 59:2582-2593

doi:10.1186/1999-3110-54-52

Cite this article as: Li et al:: Detection and identification of the

phytoplasma associated with China ixeris (Ixeridium chinense) fasciation. Botanical Studies 2013 54:52.

\section{Submit your manuscript to a SpringerOpen ${ }^{\circ}$} journal and benefit from:

- Convenient online submission

- Rigorous peer review

- Immediate publication on acceptance

- Open access: articles freely available online

- High visibility within the field

- Retaining the copyright to your article

Submit your next manuscript at $>$ springeropen.com 